\section{Asymmetric anhidrosis in MSA}

C. Saft, MD, J. Andrich, MD, M. Stücker, MD,

H. Przuntek, MD, and T. Müller, MD, Bochum, Germany

Thermodysregulation with loss of sweating is a common feature of dysautonomia in multiple system atrophy (MSA)., ${ }^{1,2}$ A 51year-old man with MSA with predominant parkinsonian motor symptoms had onset of asymmetric anhidrosis of the trunk and the preponderant lower limbs. The ninhydrin test revealed reduced sweating in all extremities. Minor test showed marked anhidrosis of lower limbs, corresponding to dermatome T10, and asymmetric sweating behavior of the trunk, corresponding to dermatome T4 (figure). A distinct depletion of sympathetic adrenergic, thoracic spinal neurons may cause this phenomenon. ${ }^{1,2}$

1. Benarroch EE, Smithson IL, Low PA, Parisi JE. Depletion of catecholaminergic neurons of the rostral ventrolateral medulla in multiple systems atrophy with autonomic failure. Ann Neurol 1998;43:156-163.

2. Cohen J, Low P, Fealey R, Sheps S, Jiang NS. Somatic and autonomic function in progressive autonomic failure and multiple system atrophy. Ann Neurol 1987;22:692-699.

Address correspondence and reprint requests to Dr. Thomas Müller, Department of Neurology, St. Josef Hospital, Ruhr University Bochum, Gudrunstrasse 56, 44791 Bochum, Germany; e-mail: thomas.mueller@ ruhr-uni-bochum.de.

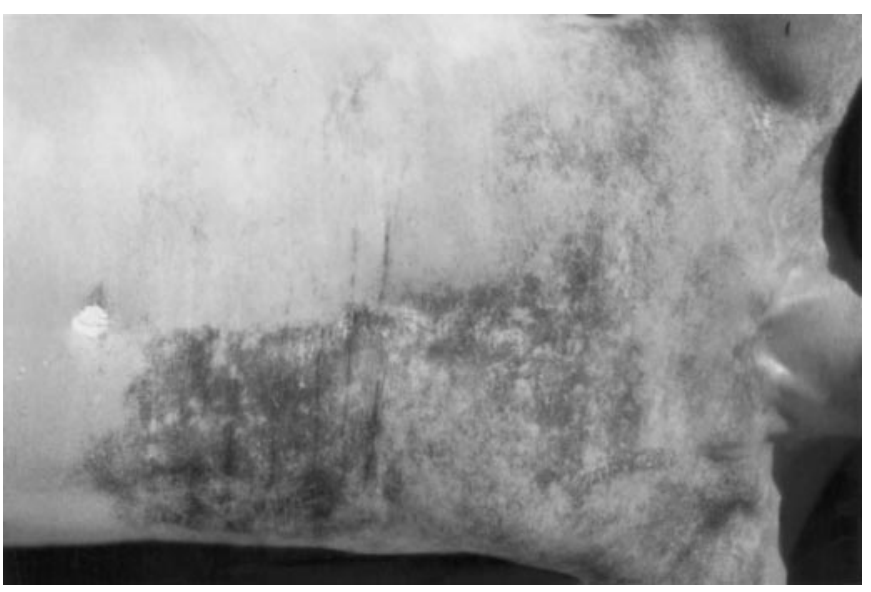

Figure. Thermodysregulation with asymmetric anhidrosis of the trunk, visualized with loss of sweating in the bright iodine glycerol covered areas. The powder turns color when exposed to moisture in regions with intact sweating. 


\section{Neurology}

Asymmetric anhidrosis in MSA

C. Saft, J. Andrich, M. Stücker, et al.

Neurology 2003;61;231

DOI 10.1212/01.WNL.0000068531.55965.F0

\section{This information is current as of July 21, 2003}

\section{Updated Information \& Services}

\section{References}

Subspecialty Collections

Permissions \& Licensing

Reprints including high resolution figures, can be found at: http://n.neurology.org/content/61/2/231.full

This article cites 2 articles, 0 of which you can access for free at: http://n.neurology.org/content/61/2/231.full\#ref-list-1

This article, along with others on similar topics, appears in the following collection(s):

Autonomic diseases

http://n.neurology.org/cgi/collection/autonomic_diseases Multiple system atrophy

http://n.neurology.org/cgi/collection/multiple_system_atrophy

Information about reproducing this article in parts (figures,tables) or in its entirety can be found online at:

http://www.neurology.org/about/about_the_journal\#permissions

Information about ordering reprints can be found online:

http://n.neurology.org/subscribers/advertise

Neurology ${ }^{\circledR}$ is the official journal of the American Academy of Neurology. Published continuously since 1951, it is now a weekly with 48 issues per year. Copyright . All rights reserved. Print ISSN: 0028-3878. Online ISSN: 1526-632X.

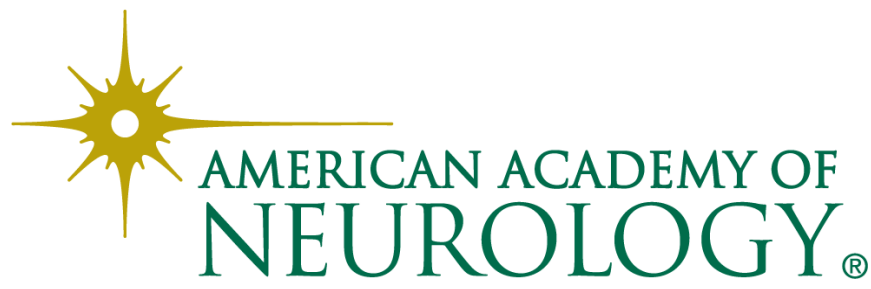

